\title{
Literature Review of Capital Structure Theory and Influencing Factors
}

\author{
Lanli Zhao \\ Jinan University, Guangzhou, China \\ Email: zhaolanli1993@163.com
}

How to cite this paper: Zhao, L.L. (2018) Literature Review of Capital Structure Theory and Influencing Factors. Modern Economy, 9, 1644-1653.

https://doi.org/10.4236/me.2018.910103

Received: September 10, 2018

Accepted: October 16, 2018

Published: October 19, 2018

Copyright $\odot 2018$ by author and Scientific Research Publishing Inc. This work is licensed under the Creative Commons Attribution International License (CC BY 4.0).

http://creativecommons.org/licenses/by/4.0/

\begin{abstract}
Modigliani and Miller [1] conducted a pioneering study on the theory of capital structure. Many scholars have drawn conclusions that are more in line with economic reality while gradually relaxing the assumptions, thus further enriching and developing the theory of capital structure of the company. Relevant theories about capital structure have gone through two stages: the old capital structure theory and the new capital structure theory. The old capital structure theory is based on a series of strict assumptions, including traditional theory, MM theory and trade-off theory. The new capital structure theory introduces modern analytical tools, such as game theory and information economics, into capital structure analysis, including agency cost theory, signal transmission theory, and superior order financing theory. The factors affecting the capital structure include macro, industry, company, and institutional levels. This paper will summarize the relevant literature at home and abroad, pay attention to the study of capital structure theory and its influencing factors, and then optimize the relevant theoretical framework to provide theoretical basis for decision-making.
\end{abstract}

\section{Keywords}

Capital Structure Theory, MM Theory, Literature, Influencing Factors

\section{Introduction}

The article is divided into three parts. The first part is a literature review on the choice of capital structure. From the literature, the research on the choice of capital structure mainly focuses on the theory of trade-offs, agency cost theory, and theory of superior order financing. The second part is research. A literature review of the influencing factors of capital structure is elaborated from domestic literature and foreign literature. From the literature, the influencing factors in- 
clude company-level factors, national-level factors, and industry factors. National-level factors include GDP and inflation. The company-level factors include scale, growth, profitability, risk, debt guarantee capability, and equity structure. The third part is a literature review on the impact of executive compensation on capital structure. The literature focuses on the impact of executive compensation levels, salary gaps, and equity incentives on capital structure.

\section{Literature Review on the Theory of Capital Structure}

Modigliani and Miller [1] conducted a groundbreaking study on the theory of capital structure, and proposed that the theory that the capital structure of the company has nothing to do with the company value in the complete market is the MM theory. The problem of the company's capital structure has been widely studied by scholars. Robichek [2] and others proposed a trade-off theory. When enterprises decide the capital structure, they must weigh the tax avoidance effect and bankruptcy cost of liabilities. Jesen and Meckling [3] proposed the agency cost theory. The theory distinguishes between two companies' conflicts of interest: the cost of equity agency caused by conflicts of interest between shareholders and managers, and the cost of debt agency caused by conflicts of interest between creditors and shareholders. Ross [4] first incorporated asymmetric information into the study of capital structure. Ross assumed that corporate managers have internal information about the company's future earnings and investment risks, while investors do not, but know the incentive system for managers, so Investors can only indirectly evaluate the market value of the company through the information sent by the manager. Corporate debt ratio or asset-liability structure is a signal tool that conveys internal information to the market. Since the probability of ruin is negatively correlated with the quality of the firm and is positively related to the level of debt, external investors regard the higher debt ratio as a signal of high quality, that is, the value of the firm and the proportion of debt are positively correlated. Myers and Majluf [5] proposed the theory of priority financing, which believes that equity financing will convey negative information about business operations, and external financing will pay more for various costs. Therefore, corporate financing generally follows internal financing, debt financing, and equity financing. In order.

The domestic literature has also done a lot of research on the choice of capital structure. Huang Shaoan and Zhang Gang [6] compared the listed companies in the United States and found that the financing behavior of Chinese listed companies has obvious equity financing preferences, while relatively neglecting debt financing. Wang Wei and Zhao Jun [7] and Xiao Zuoping [8] analyze the relationship between capital structure and company characteristics. The study finds that there is an optimal capital structure in China's listed companies, and when there is a deviation between the actual capital structure and the optimal capital structure, Adjustments will be made, but compared to developed countries, adjustments are slower and asymmetric. Zhu Dexin and Zhu Hongliang [9] use 
Chinese data research to find that balance theory and superior order theory cannot explain the choice of Chinese enterprises' capital structure separately. The choice of capital structure of Chinese listed companies may reflect the operator's camera under specific financial conditions. The choice, at the same time, is largely influenced by external constraints.

\section{Literature Review on the Influencing Factors of Capital Structure}

\subsection{Foreign Literature Review}

From the perspective of the company's impact on the capital structure, according to Giannetti [10] found that the capital structure of companies in some developed countries is affected by the same company-level variables. Titman and Wessels [11] argue that the main factors affecting a company's capital structure include the asset collateral value of the company, the size of the company, and the non-debt tax rate. According to Frank and Goyal [12], the factors affecting the company's leverage include the median industrial leverage, market capitalization to book ratio, debt guarantee ability, profitability, dividend payment, asset logarithm, and the fixed effect of the company or manager. Their research in 2008 shows that from the perspective of company-level variables, there is a significant correlation between profitability, growth and other indicators and capital structure. From an industry perspective, the degree of competition between product markets and financial leverage in different industries There are mutual influences. According to AD Jong, R Kabir, TT Nguyen [13], they believe that the company-level variables that determine the capital structure are debt guarantee capacity (net fixed assets/total assets book), risk (standard deviation of the ratio of operating income to total assets book), company size (logarithm of total sales), tax rate (annual average tax rate), development opportunities (ratio of total assets to market value to book value), profitability (ratio of operating income to total asset book value), liquidity (flow The ratio of assets to current liabilities), as well as industry dummy variables. According to R Gropp and F Heider [14], the company-level variables of the bank include MTB (the ratio of asset market value to book value), profitability ((pre-tax profit + interest)/total asset book value), size (total assets book value) The logarithm), the value of the collateral (Coll), the dummy variable of the dividend payment (or 1 if the bank paid the dividend in the current year), and the fixed effect variable of the time and country.

From the perspective of the impact of the capital structure on the national level, Korajczyk and Levy [15] used the company's overall profitability, short-term interest rates, maturity spreads and credit spreads to measure macroeconomic conditions, and found that the financial constraints of $90 \%$ of the sample size were loose. The change of the asset-liability ratio of the enterprise is in the anti-economic cycle mode, which is consistent with the financing order theory; while the asset-liability ratio change of the financially tight enterprise accounting 
for $10 \%$ of the sample size is in the economic cycle mode, which is consistent with the trade-off theory. Bancel and Mittoo [16] argue that the legal environment in different countries has an important impact on the company's capital structure. According to AD Jong, R Kabir, TT Nguyen [13] from the bond market structure (bond market development, creditor power protection, law enforcement perfection), stock market structure (shareholder power protection, stock positioning level), capital formation rate and GDP growth rate Four aspects examine the direct and indirect effects of national factors on capital structure.

From the perspective of the influence of executive stock ownership on capital structure, according to the agency cost theory, scholars have conducted a lot of research on the relationship between managerial shareholding and corporate capital structure, and the conclusions are not the same. Negative correlations may also exhibit a significant positive correlation and may also be in a U-shaped relationship. The relevant research literature is as follows.

Jesen, Solberg, and Zorn [17] studied the relationship between managerial shareholdings and liabilities, and the results showed that managerial shareholding, R \& D spending, profitability, business risk, and dividend policy have a negative relationship with the debt ratio. There is a positive relationship to the debt ratio. Mohd, Perry, and Rimbey [18] studied the impact of the company's shareholding structure on the company's capital structure. The results showed that managerial shareholding, corporate risk, company performance, R \& D spending, and institutional shareholding have a negative relationship with the debt ratio. The degree of equity dispersion has a positive relationship with the debt ratio. Brailsford [19] found that managers' shareholdings and debt ratios have a U-shaped relationship. Frank and Goyal [20] show that executives hold less than $1 \%$ of shares, and leverage will increase as shareholding increases, while executives hold more than $5 \%$. As executives increase their holdings, corporate leverage will decrease. When executives hold more than $1 \%$ but less than $5 \%$, there is no significant relationship between executive holdings and leverage levels.

There is also a growing body of literature discussing the impact of pay performance sensitivity on corporate financial decisions. According to MC Jensen, KJ Murphy [21], executive compensation performance sensitivity includes cash compensation, options, equity, dismissal, and found that incentives from stocks and options are much greater than incentives from wages and bonuses. Starting with Core and Guay [22], stocks and options are used to estimate the sensitivity of pay performance, and the change in the specific wealth of executives is equal to the change in stock-related wealth. Frank and Goyal [18] argue that PPS has a significant negative correlation with corporate leverage, and that executive stock holdings have different relationships with corporate leverage to varying degrees. Brockman [23] believes that executive compensation affects managers' risk appetite through the sensitivity of executive portfolios to stock price and stock in- 
come fluctuations, which proves that portfolio sensitivity is negatively correlated with short-term debt, and portfolios fluctuate against stock income. Sensitivity is positively correlated with short-term debt. Michael Albert [24] argues that Pay Performance Sensitivity (PPS) is significantly negatively correlated with corporate leverage, and this negative correlation is due to the relationship between PPS and the cost of bankruptcy of individual companies.

\subsection{Domestic Literature Review}

Xiao Zuoping [8] reviewed the research on the factors affecting capital structure, which are divided into four major aspects: macroeconomic factors, industry factors, company characteristics factors, and corporate governance structure factors.

Judging from the influence of company-level factors on capital structure, Zhang Zebin, Zhu Shaoxing, Wu Jianzhong [25] studied the influencing factors of listed companies' capital structure, selected 943 listed companies in Shenzhen and Shanghai as samples and used 1998 cross-section data as Based on the empirical research, the results show that the growth of the listed company, the size of the company and the debt ratio are positively correlated, and the retained earnings, corporate asset profitability and debt ratio are negatively correlated. Su Dongwei and Zeng Haijian [26] believe that company-level variables include scale (LNSALES), debt guarantee capability (TANGIBLE), non-debt tax shield (NDTS), age (AGE), profitability (ROA), and profit fluctuation (STDROA). Development Opportunities (Tobin's Q), shareholding structure (the largest shareholder share ratio LARGEST and non-tradable shares ratio NONTRADE). Feng Genfu [27] believes that company-level variables affecting the company's capital structure include profitability (ROE), risk (standard deviation of ROE), debt guarantee ability (fixed assets to total assets ratio), company size (total assets logarithm), equity Structure (legal share ratio FRG and state-owned share ratio GYG).

Judging from the influence of industry factors on capital structure, Lu Zhengfei and Xin $\mathrm{Yu}$ [28] studied the influencing factors of listed companies' capital structure, and used multiple regression methods to conduct statistical research on 35 listed manufacturing A-share listed companies in Shanghai Stock Exchange in 1996. The results show that the capital structure of different industries has significant differences, and the profitability is significantly negatively correlated with the capital structure, while the factors such as scale, asset guarantee value and growth have no significant impact on the capital structure.

Judging from the influence of ownership structure on capital structure, $\mathrm{Hu}$ Guoliu and Dong Wei [29] used the public data of A-share companies listed in Shanghai and Shenzhen from 1998 to 2002 as observations, and found that managers' shareholding and shareholding concentration have a significant impact on the choice of corporate capital structure. The existence of the state-owned stocks and circulation stocks has little impact on the capital struc- 
ture of enterprises, and the proportion of legal person shares has a certain impact on the capital structure. Gu Naikang and Yang Tao [30] based on the agency theory of capital structure, the research shows that the ownership structure is an important determinant of capital structure, and the change of ownership structure will also produce dynamic adjustment of capital structure. The impact, in which the shareholding ratio of managers and the proportion of state shares are significantly positively correlated with the debt ratio. The study also shows that the company's growth, scale, non-debt tax shield and profitability are also important factors affecting the capital structure of listed companies in China. Feng Genfu and Ma Yajun [27] have shown that listed company executives have the motivation to adjust the company's debt level for self-interest. The existence of legal person shares has a restrictive effect on the ability of senior executives to adjust their capital structure for self-interest, but at a high level. When the management of the company has a high degree of ownership, the legal person shares also have a certain role in promoting the self-interest of the executives and the interests of other shareholders, while the role of the state-owned shares is not obvious.

Political connections also have an impact on the capital structure. Zhao Yuheng, Xing Lihui, Sun Yue [31] selected the listed companies in China's Shanghai and Shenzhen stock markets from 2007 to 2012 as a sample, and found that the political connections in private enterprises have a more significant impact on the relationship between equity incentives and capital structure. The impact of cash compensation incentives and capital structure is more pronounced.

\section{Literature Review of the Impact of Executive Compensation on Capital Structure}

Company executives are responsible for making decisions about the choice of capital structure. Executive compensation and capital structure are mutually influential endogenous relationships. Many literatures have studied the impact of capital structure on executive compensation. Scholars have adopted theoretical models and empirical tests. There is indeed a positive correlation between capital structure and executive compensation, and this positive correlation is caused by high debt levels that increase the company's bankruptcy costs and thus negative incentives for executives. These studies support the conclusion that capital structure affects executive compensation by affecting the cost of human capital bankruptcy.

From the perspective of the impact of executive compensation on capital structure, Meng Science [32] proves that executive compensation and capital structure are born within the company's internal governance. The factors affecting the endogenous relationship between the two are mainly from the company's profitability and company. Governance structure and potential strategic risk management capabilities. When there is a management defense, executive compensation also has an impact on the capital structure. When there is a manage- 
ment defense, the management who seeks to maximize its own interests will choose a more conservative capital structure than the shareholder value to avoid the risk of human capital bankruptcy. According to Wang Zhiqiang, Zhang Yuting and GuJiner [33], there is a significant negative correlation between executive compensation level and capital structure. It is believed that when shareholder supervision is difficult or unsupervised, the company has a management defense behavior. Lowering the capital structure, on the other hand, raising its own salary level and maximizing its own value. The listed companies in China all have the phenomenon of management defense. Compared with private enterprises, the management of state-owned enterprises has a higher degree of defense.

In summary, there is little literature on the impact of executive compensation on capital structure in domestic literature, but mainly on the impact of capital structure on executive compensation, while existing domestic and foreign literatures are studying the relationship between executive compensation and capital structure. The impact is mainly on the impact of executive stock holdings on leverage ratio, especially the domestic literature rarely involves the impact of executive compensation structure on capital structure.

According to the influence of equity incentive factors on the capital structure, according to the principal-agent theory, because the utility functions of the company's principal and agent are different, the agent may have behaviors that infringe upon the interests of the principal. Jesen and Meckling [3] pioneered the introduction of equity incentives to coordinate the interests of managers and shareholders. When the shareholding ratio of senior executives is relatively high, their goals will be consistent with shareholder goals to a certain extent. Pay more attention to the company's long-term development and market performance. For executives who receive both annual salary and shares, the annual salary guarantees that they will pay attention to the company's performance in the short term, and on the other hand, the equity will also avoid their short-term behavior at the expense of future development. The salary composition of listed bank executives is mainly the annual salary and shareholding incentives. The annual salary is a relatively fixed income and is an assessment and recognition of the work of the senior executives during the year. Compared with the annual salary, holding equity is a long-term incentive, allowing executives to pay more attention to the company's market value.

According to Guo Wei and GuHaiying [34], there is a positive correlation between executive stock market value and company performance. The higher the stock market value, the greater the equity incentives, the executives are likely to adopt a more aggressive financial policy, choose a higher leverage ratio, to improve their performance in order to obtain promotion and salary increase and equity market value, which may give the company Bring greater risks. Therefore, executives holding stock market values will affect the decision of capital structure. 
Scholars have done a lot of research on the relationship between the shareholding ratio of managers and the company's capital structure, and the conclusions are different. The two may have negative correlations or significant positive correlations, and may also have a U-shaped relationship. Mohd, Perry, and Rimbey [18] studied the impact of the company's shareholding structure on the company's capital structure. The results show that the manager's shareholding has a negative relationship with the debt ratio. Brailsford [19] found that managers' shareholdings and debt ratios have a U-shaped relationship. Lv Changjiang and Wang Kemin [35] included the analysis of the shareholding ratio of managers for the first time, and studied the relationship between capital structure, dividend distribution and shareholding ratio of listed companies by three-stage least squares method. The sample is Shenzhen and Shanghai. 231 companies from 1997 to 1999, the empirical results show that the proportion of managers holding shares will significantly affect the company's capital structure, the higher the proportion of managers, the lower the debt ratio of the company, in addition, in the growth stage, The profitable companies with gradually expanding assets have a good financial leverage and a high debt ratio.

Through literature review, it can be found that when the literature studies the factors affecting the capital structure, the company-level variables are mainly concentrated in the company size, debt guarantee capability, non-debt tax shield, profitability, development opportunities and so on. There is little literature on the impact of executive compensation on capital structure in domestic literature, but mainly on the impact of capital structure on executive compensation, while existing domestic and foreign literature studies the impact of executive compensation on capital structure. Mainly focused on the impact of executive stock ownership on leverage ratio, especially the domestic literature rarely involves the impact of executive compensation structure on capital structure.

\section{Conflicts of Interest}

The authors declare no conflicts of interest regarding the publication of this paper.

\section{References}

[1] Modigliani and Miller (1958) American Economic Association the Cost of Capital, Corporation Finance and the Theory of Investment. The American Economic Review, 48, 261-297.

[2] Robichek, A.A. and Myers, S.C. (1966) Problems in the Theory of Optimal Capital Structure. Journal of Financial \& Quantitative Analysis, 1, 1-35. https://doi.org/10.2307/2329989

[3] Jensen, M.B. and Meckling, W. (1976) Theory of the Firm: Managerial Behavior, Agency Cost and Ownership Structure. Social Science Electronic Publishing, 3, 305-360. https://doi.org/10.1016/0304-405X(76)90026-X

[4] Ross, S.A. (1977) The Determination of Financial Structure: The Incentive-Signalling Approach. Bell Journal of Economics, 8, 23-40. https://doi.org/10.2307/3003485 
[5] Myers, S.C. and Majluf, N.S. (2001) Corporate Financing Decisions When Firms Have Investment Information that Investors Do Not. Journal of Financial Economics, 13, 187-221. https://doi.org/10.1016/0304-405X(84)90023-0

[6] Huang, S.A. and Zhang, G. (2001) Analysis on the Preference of Equity Financing. Economic Research, No. 11, 12-20+27.

[7] Wang, W. and Zhao, J. (2004) Dynamic Adjustment Model of Capital Structure-An Empirical Analysis of Shanghai and Shenzhen Stock Markets. Economic Science, No. 3, 54-62.

[8] Xiao, Z.P. (2004) Influencing Factors of Capital Structure and Dynamic Model of Two-Way Effect-Evidence from Panel Data of Chinese Listed Companies. Accounting Research, No. 2, 98-103.

[9] Zhu, D.X. and Zhu, H.L. (2007) The Choice of Capital Structure of Chinese Listed Companies-Based on the Test of Two Main Theories. Southern Economy, No. 9, 30-37.

[10] Giannetti, M. (2003) Do Better Institutions Mitigate Agency Problems? Evidence from Corporate Finance Choices. Journal of Financial \& Quantitative Analysis, 38, 185-212. https://doi.org/10.2307/4126769

[11] Titman, S. and Wessels, R. (1988) The Determinants of Capital Structure Choice. Journal of Finance, 43, 1-19. https://doi.org/10.1111/j.1540-6261.1988.tb02585.x

[12] Frank, M.Z. and Goyal, V.K. (2003) Testing the Pecking Order Theory of Capital Structure. Journal of Financial Economics, 67, 217-248.

https://doi.org/10.1016/S0304-405X(02)00252-0

[13] Jong, A.D., Kabir, R. and Nguyen, T.T. (2008) Capital Structure around the World: The Roles of Firm- and Country-Specific Determinants. Journal of Banking \& Finance, 32, 1954-1969. https://doi.org/10.1016/j.jbankfin.2007.12.034

[14] Gropp, R. and Heider, F. (2009) The Determinants of Bank Capital Structure. Social Science Electronic Publishing, 14, 587-622.

[15] Korajczyk, R.A. and Levy, A. (2003) Capital Structure Choice: Macroeconomic Conditions and Financial Constraints. Journal of Financial Economics, 68, 75-109. https://doi.org/10.1016/S0304-405X(02)00249-0

[16] Bancel, F. and Mittoo, U.R. (2004) Cross-Country Determinants of Capital Structure Choice: A Survey of European Firms. Financial Management, 33, 103-132.

[17] Jensen, G.R., Solberg, D.P. and Zorn, T.S. (1992) Simultaneous Determination of Insider Ownership, Debt, and Dividend Policies. Journal of Financial \& Quantitative Analysis, 27, 247-263. https://doi.org/10.2307/2331370

[18] Moh'D, M.A., Perry, L.G. and Rimbey, J.N. (2010) The Impact of Ownership Structure on Corporate Debt Policy: A Time-Series Cross-Sectional Analysis. Financial Review, 33, 85-98.

[19] Brailsford, T.J., Oliver, B.R. and Pua, S.L.H. (2002) On the Relation between Ownership Structure and Capital Structure. Accounting \& Finance, 42, 1-26. https://doi.org/10.1111/1467-629X.00001

[20] Frank, M.Z. and Goyal, V.K. (2007) Corporate Leverage: How Much Do Managers Really Matter? Social Science Electronic Publishing.

[21] Jensen, M. and Murphy, K. (1990) Performance Pay and Top-Management Incentives. Journal of Political Economy, 98, 225-264. https://doi.org/10.1086/261677

[22] Core, J.E. and Guay, W.R. (2001) The Other Side of the Trade-Off: The Impact of Risk on Executive Compensation: A Revised Comment. Social Science Electronic Publishing, 2, 395-402. https://doi.org/10.2139/ssrn.292955 
[23] Brockman, P., Martin, X. and Unlu, E. (2010) Executive Compensation and the Maturity Structure of Corporate Debt. Journal of Finance, 65, 1123-1161. https://doi.org/10.1111/j.1540-6261.2010.01563.x

[24] Albert, M. (2013) Executive Compensation and Firm Leverage.

[25] Zhang, Z., Zhu, S. and Wu, J. (2000) Factors Affecting the Capital Structure of Listed Companies. Journal of Systems Management, 9, 106-112.

[26] Su, D. and Zeng, H. (2009) Macroeconomic Factors and Changes in Corporate Capital Structure. Economic Research, No. 12, 52-65.

[27] Feng, G. and Ma, Y. (2004) An Empirical Analysis of the Impact of Self-Interest of Listed Companies on Capital Structure. Finance and Trade Economics, No. 6, 16-22.

[28] Lu, Z. and Xin, Y. (1998) An Empirical Study on the Main Influencing Factors of Capital Structure of Listed Companies. Accounting Research, No. 8, 34-37.

[29] Hu, G. and Dong, W. (2005) An Empirical Analysis of the Equity Structure and Capital Structure Selection of Listed Companies. Finance and Economics, No. 5, 90-98.

[30] Gu, N. and Yang, T. (2004) An Empirical Study of the Impact of Ownership Structure on Capital Structure. Journal of Sun Yatsen University, No. 1, 92-127.

[31] Zhao, Y., Xing, L. and Sun, Y. (2016) Political Relations, Executive Incentives and Capital Structure. Management Review, No. 11, 150-161.

[32] Meng Science (2009) The Endogenous Relationship between Corporate Executive Compensation and Financing Structure. Journal of Zhongnan University of Economics and Law, No. 5, 101-105.

[33] Wang, Z., Zhang, Y. and Gu, J. (2011) Capital Structure, Management Defense and Executive Compensation Level of Listed Companies. Accounting Research, No. 2, 72-79.

[34] Guo, W. and Gu, H. (2008) The Impact of Executive Compensation Structure on Business Performance. East China Economic Management, No. 4, 100-103.

[35] Lu, C. and Wang, K. (2002) Research on the Interaction Mechanism of Capital Structure, Dividend Distribution and Management Equity Ratio of Listed Companies. Accounting Research, No. 3, 39-48. 